\title{
A Waste Energy Recovery Management for Electricity Generation from Two Temperature Grades of Energy Sources in Subcritical Organic Rankine Systems
}

\begin{abstract}
By Ali H. Tarrad
Waste energy represents one of the most critical issues for the economic utilization and management of energy in modern industrial fields. This article outlines a scheme to utilize two different source temperature levels within the envelope of higher than $200{ }^{\circ} \mathrm{C}$ zones. Two regenerative organic Rankine cycles (RORC) were implemented to construct a compound regenerative organic Rankine cycle (CRORC) to improve the energy management of the sources. These two mini-cycles were integrated throughout an intermediate economizer circuit to extract a certain amount of energy from the high-temperature level mini-cycle. $R$-123 was circulated in the high-temperature cycle due to its high critical temperature at evaporation and condensation temperatures of $160{ }^{\circ} \mathrm{C}$ and $50{ }^{\circ} \mathrm{C}$, respectively. $R-123, R-21$, and hydrocarbon $R-600$ were used as working fluids for the low-temperature cycle at evaporation and condensation temperatures of $130{ }^{\circ} \mathrm{C}$ and $35^{\circ} \mathrm{C}$, respectively. The $R$ - 123 fluid in the hightemperature mini-cycle was superheated to $170-240^{\circ} \mathrm{C}$, whereas the fluid in the low-temperature level was superheated to $180{ }^{\circ} \mathrm{C}$. The results showed that the independent system (IRORC) requires more energy recovery than the compound system by a maximum of $2 \%$ to achieve the same net power output. This corresponds to the enhancement of $2 \%$ for the system net thermal efficiency of the compound (CRORC) system compared to the independent (IRORC) one. The compound (CRORC) system revealed a net thermal efficiency in the range of $14 \%$ and $15.6 \%$ for the test conditions. The mini-cycle net thermal efficiency of the low-temperature in the compound system was enhanced by a range of $2.5-5 \%$ compared to that of the independent arrangement. $R-123 / R-123$ and $R$ $123 / R-21$ systems exhibited higher net thermal efficiencies than the $R-123 / R-600$ one by $3 \%$ and $2 \%$, respectively. Increasing the superheat degree of the hightemperature mini-cycle from $10{ }^{\circ} \mathrm{C}$ to $80{ }^{\circ} \mathrm{C}$ for the compound system has improved the thermal efficiency by 7.6-7.9\% for the examined fluid pairs and operating conditions.
\end{abstract}

Keywords: compound cycle, regenerative, energy management, energy recovery, organic fluids

\section{Introduction}

Astina (2010) compared the direct expansion steam turbine, binary cycle (Organic Rankine Cycle, ORC), and heat pumped geothermal power plant performance. The ORC with working fluids R-134a and R-600a performs better than the direct expansion cycle when operated at lower geothermal source

\footnotetext{
"Professor, University of Lorraine, CNRS, LEMTA, F-54000 Nancy, France.
} 
temperature. He concluded that the direct expansion cycle performs better when the steam temperature is higher than $150{ }^{\circ} \mathrm{C}$. Therefore, including a gas turbine system in a geothermal power plant can improve the system's efficiency. Shengjun et al. (2011) investigated the utilization of an organic Rankine cycle (ORC) working at $80-100{ }^{\circ} \mathrm{C}$. Their results proved that R-600a demanded the lowest cost to produce electricity, and the R-152 unit is more compactable. Vankeirsbilck et al. (2011) found that the (ORC) can be operated on low-temperature heat sources grades with low to moderate evaporation pressure and still achieve a better performance than that of a steam cycle under the same conditions.

$\mathrm{Xi}$ et al. (2013) compared the performance of different (ORC) technologies. They found that the double-stage regenerative cycle produced the best thermal and exergy efficiency under the optimal operating conditions. It was followed by the single-stage regenerative system (RORC), and the simple organic Rankine cycle (SORC) has the worst efficiencies. Molés et al. (2014) investigated the performance of R-1233zd-E, R-1336mzz-Z, and R-245fa fluids in an (ORC). They concluded that R-1233zd-E requires $10.3 \%$ to $17.3 \%$ lower pump power and provides up to $10.6 \%$ higher cycle efficiency than R-245fa over the tested range of cycle conditions. They also postulated that the turbine size for R-1233zd-E would be about $7.5 \%$ to $10.2 \%$ larger than for R-245fa. Jung et al. (2015) studied the performance of a zeotropic fluid mixture of R-245fa and R365mfc (48.5\%/51.5\% on a mole basis) in a lab-scale ORC. They found that the electricity generated at a steady state was about $70 \%$ of the nominal capacity of the scroll expander. The ORC system efficiency resulting from the experiment was approximately $3.9 \%$.

Javanshir et al. (2017) investigated a regenerative organic Rankine cycle (RORC) performance using dry working fluids. R-600, R-600a, and R113 offer the highest specific net of work output. They concluded that the circulated fluid's specific heat and critical temperature affect the thermal performance of the cycle. The higher cycle net of work output and thermal efficiency correspond to the working fluids that possess higher specific heat and higher critical temperature, respectively. Mishra and Khan (2017) performed the exergy and energy analysis of the organic Rankine cycle with the solar heating source, and bleeding regeneration was implemented in the (RORC). The system's performance was compared with different organic fluids such as R134a, R407C, R404A, and $\mathrm{R} 410 \mathrm{~A}$ at different organic Rankine cycle maximum temperatures and pressures. R410A showed a maximum efficiency by regeneration around 64\%. R410A showed the maximum organic Rankine cycle efficiency of $16.51 \%$. They concluded that thermal efficiency for the plant increases with the inlet temperature increase of the expander.

Yazdi (2017) evaluated analytically three different ORC cycles; they were basic ORC, regenerative ORC, and ORC with an internal heat exchanger (IHE). The IHE heats the working fluid from the pump outlet to the open feed organic heater inlet condition and cools the saturated vapor of working fluid from the outlet condition of the turbine to the condenser inlet condition. In addition, flashing pressure and extraction pressure optimization of these cycles was performed. According to this study, the best cycle, which gives maximum thermal and exergy efficiency to a flash-binary power plant, is a regenerative ORC with 
IHE, which is on average $1.22 \%$ higher than basic ORC. Yuan and Zhang (2019) investigated the thermal performance of eight candidate working fluids R-123, R245fa, R-114, R-236ea, R-236fa, RC318, R-227ea, and R-1234yf with a low heat source grade of $100-150{ }^{\circ} \mathrm{C}$. They concluded that the heat source temperature and its allowable minimum temperature at the outlet port influence the optimal turbine inlet condition state. Further, the optimal condition state is also affected by the critical temperature of the working fluid.

Pandey et al. (2018) studied the zeotropic mixture of R-600a/DME at different composition values. They found that R600a/DME (0.8/0.2) gives the maximum net of work output corresponding to $(70){ }^{\circ} \mathrm{C}$ inlet temperature to the evaporator. Among all selected proportions, R600a/DME (0.6/0.4) has both maximum thermal efficiency and maximum exergy efficiency corresponding to $100{ }^{\circ} \mathrm{C}$ inlet temperature to the evaporator. Da Cunha and Souza (2020) simulated a regenerative organic Rankine cycle (RORC) with fluid bleeding at the turbine; R$134 \mathrm{a}$ was chosen as a working fluid. The evaporation temperature was ranged between $60{ }^{\circ} \mathrm{C}$ and $100{ }^{\circ} \mathrm{C}$ with superheated temperatures of $120{ }^{\circ} \mathrm{C}, 200{ }^{\circ} \mathrm{C}$, and $300{ }^{\circ} \mathrm{C}$. They concluded that the maximum thermal efficiency and turbine output increase with the evaporation temperature. The turbine output power showed an augmentation with increasing superheat temperatures, and the thermal efficiency exhibited a declination with superheat temperature increase. Tarrad (2020a) investigated the thermal performance of a simple organic Rankine cycle (SORC) when circulated various organic fluids at low-temperature levels. He found that the thermal efficiencies of R-134a, R-123, R-245fa, R-1233zd-E, and R-1234ze-E were higher than that of R-290 by $10-14 \%, 11-12 \%, 9-12 \%, 4-7 \%$, and $1-3 \%$, respectively. R-290 exhibited thermal efficiencies close to R-1233zd-E and R$1234 \mathrm{ze}-\mathrm{E}$ in the superheat degree range of $5-15^{\circ} \mathrm{C}$.

Tarrad (2020b) investigated the performance of a regenerative (RORC) cycle arrangement when it is circulating R-123, R-1233zd-E, R-245fa, and R600a as candidate working fluids at boiling and condensation temperatures of $130{ }^{\circ} \mathrm{C}$ and $45^{\circ} \mathrm{C}$, respectively. The (RORC) showed higher thermal efficiency than that of the simple one (SORC) by the range of $8-15 \%$ for the test fluids and operating conditions. The attained maximum and minimum cycle thermal efficiencies were $12 \%$ and $10.7 \%$ for R-600a and R-1233zd-E, respectively, at $15{ }^{\circ} \mathrm{C}$ superheat degree. Tarrad (2021) investigated the performance of a compound system where two temperature levels existed for the heat sources. The lower part of the compound cycle represents the low-temperature cycle. One of the R-123, R-245fa, R-1233zd-E, or R-600a fluids was circulated in the low-temperature level of 130 ${ }^{\circ} \mathrm{C}$ and $35{ }^{\circ} \mathrm{C}$ evaporation and condensation temperatures, respectively. R-123 was circulated at the high-temperature level of the system at $150{ }^{\circ} \mathrm{C}$ and $50{ }^{\circ} \mathrm{C}$ evaporation and condensation temperatures, respectively. His study showed that the independent system needed energy consumption of about $2 \%$ higher than that of the compound system when operating under the same conditions to produce the same net power output.

This work compared the thermal performance of a compound regenerative organic Rankine cycle (CRORC) system to that of the independent regenerative organic Rankine cycle (IRORC) system under the same operating conditions. 
Three organic fluids, R-123, R-21, and R-600, were studied as candidate working fluids. Three fluid pairs were utilized to evaluate the thermal performance of the postulated system as R-123/R-123, R-123/R-21, and R-123/R-600. A hypothetical organic Rankine cycle of nominal heat recovery of $100 \mathrm{~kW}$ was implemented to evaluate the cycle performance. The low-temperature waste heat source was suggested to be available at a level higher than $200{ }^{\circ} \mathrm{C}$. The superheat degrees of $10-80{ }^{\circ} \mathrm{C}$ and $50{ }^{\circ} \mathrm{C}$ were utilized for the high-temperature and low-temperature levels of the fluids in the mini-cycles, respectively.

\section{Compound Cycle}

This cycle was initially postulated by Tarrad (2021), as presented in Figure 1. The suggested scheme outlined two regenerative (RORC) cycles integrated and combined by an intermediate economizer for energy management purposes. The upper part of the system is a regenerative cycle representing the high-temperature grade; R-123 was circulated at $160{ }^{\circ} \mathrm{C}$ and $50{ }^{\circ} \mathrm{C}$ evaporation and condensation temperatures, respectively. The lower part of the compound cycle represents the low-temperature grade where one of the R-123, R-21, or R-600 fluids was circulated at $130{ }^{\circ} \mathrm{C}$ and $35{ }^{\circ} \mathrm{C}$ evaporation and condensation temperatures, respectively.

An $8 \%$ of R-123 mass flow rate of the high-temperature cycle fluid was extracted at point (A), Figure 1, and passed through the economizer. This amount of fluid bypass was inferred from keeping a constant terminal temperature difference between condensate and the low-temperature fluid at the exit side of the condensation zone of the economizer, as shown schematically in Figure 2.

In the present work, a value of $2{ }^{\circ} \mathrm{C}$ was considered as a maximum terminal temperature difference $\left(\Delta T_{\text {ter }}\right)$ to ensure a complete condensation of the bypassed fluid amount in the economizer and avoid any economic impact. More detailed process descriptions are to be found in Tarrad (2021). 
Figure 1. A Schematic Diagram of the Postulated Compound Cycle, Tarrad (2021)

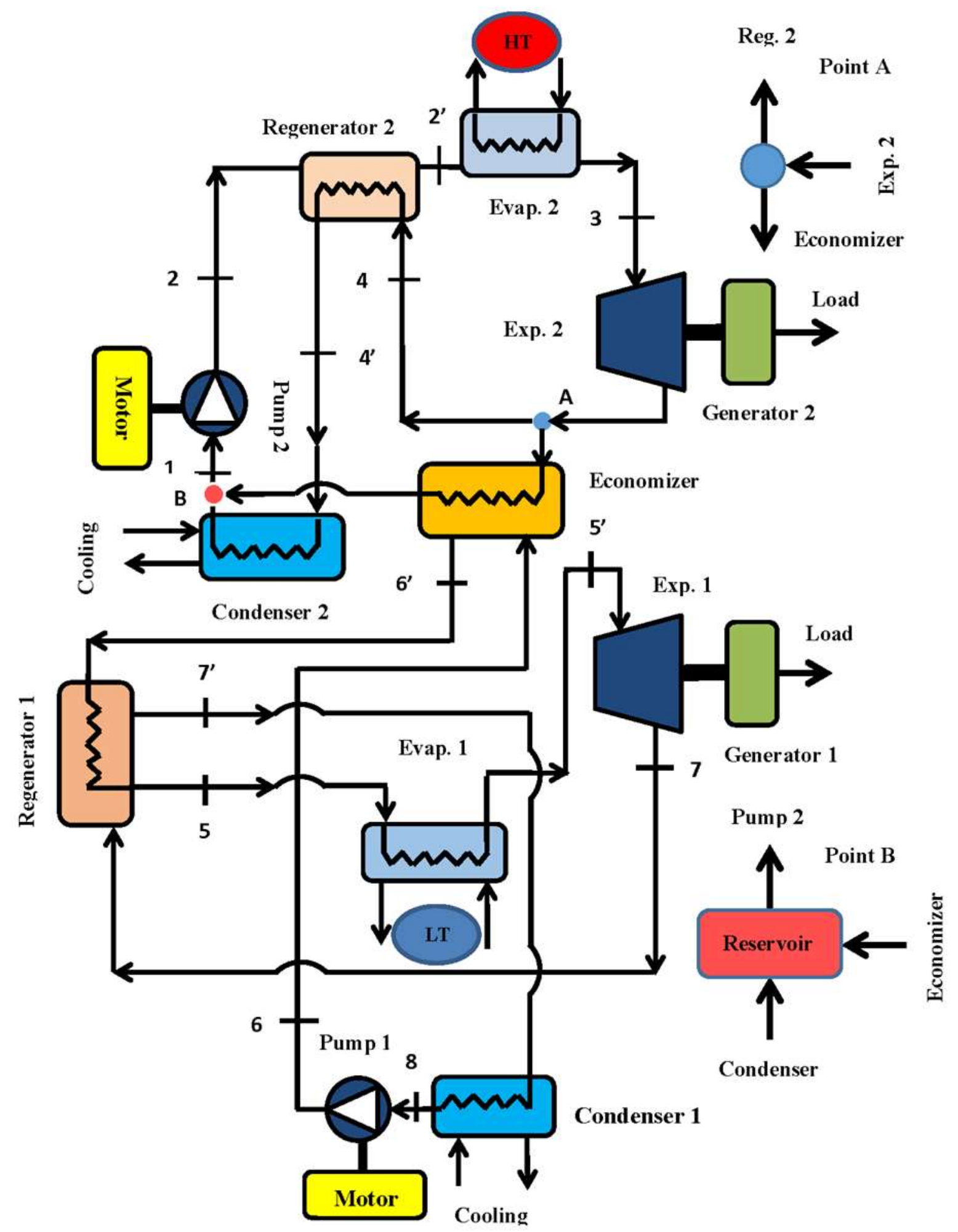


Figure 2. Fluid Temperature Variation in the Economizer

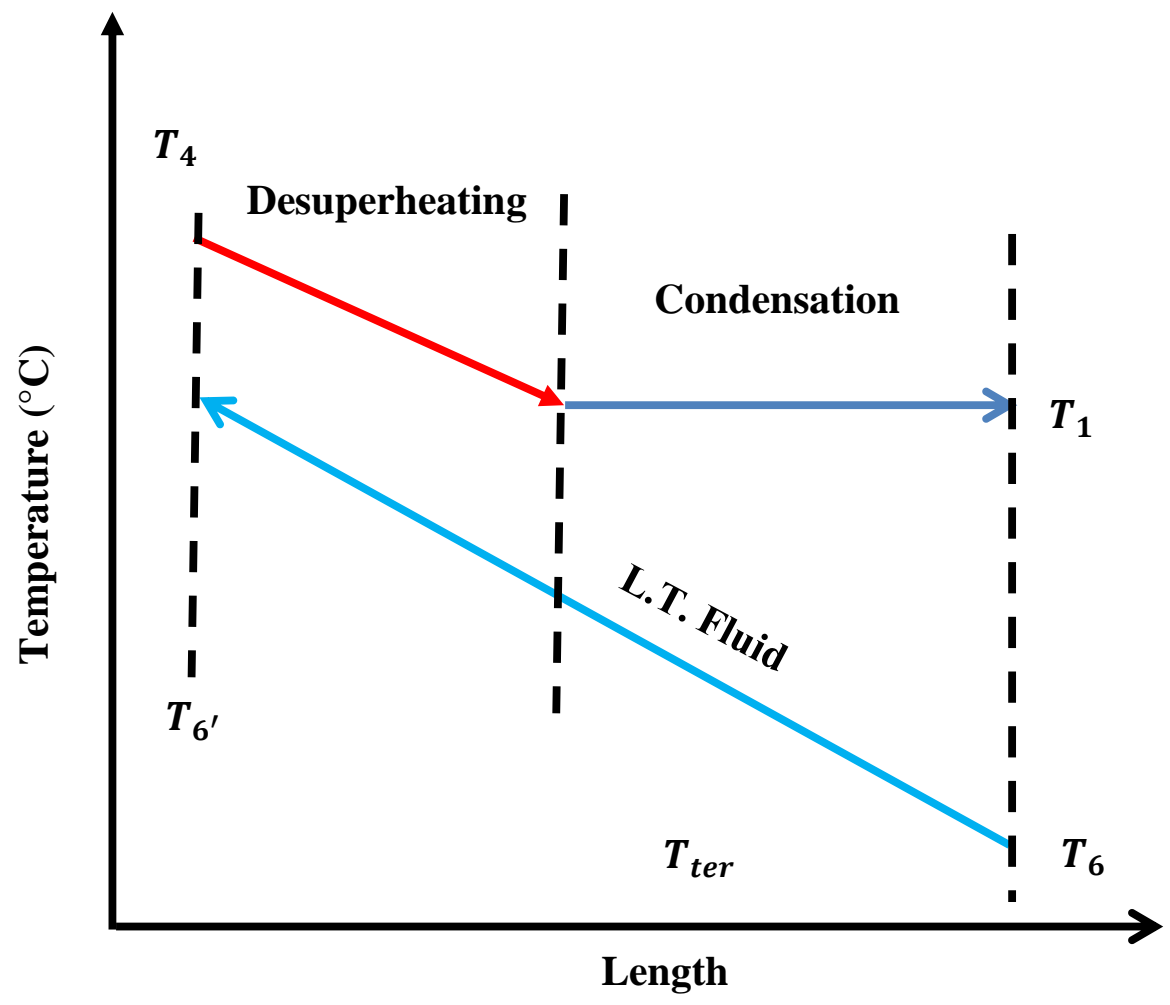

\section{Methodology}

\section{Organic Fluids}

Table 1 shows some of the physical, safety, and environmental characteristics of the selected working fluids. Three organics were selected as working fluids to circulate in the suggested compound regenerative organic Rankine cycles (CRORC). The global warming potential (GWP), Ozone depletion potential (ODP), and critical point characteristics play an essential role in the choice process of the working fluids.

Table 1. Characteristics of Test Candidate Fluids

\begin{tabular}{|c|c|c|c|c|c|c|c|c|}
\hline \multirow{2}{*}{ Refrigerant } & \multirow{2}{*}{$\begin{array}{l}\text { Chemical } \\
\text { Formula }\end{array}$} & \multirow{2}{*}{$\begin{array}{c}\mathbf{T}_{\mathbf{c}} \\
\left({ }^{\circ} \mathbf{C}\right)\end{array}$} & \multirow{2}{*}{$\underset{(\mathbf{b a r})}{\mathbf{p}_{\mathbf{c}}}$} & \multirow{2}{*}{$\begin{array}{c}\mathbf{M}_{\mathrm{w}} \\
(\mathrm{gr} / \mathrm{mol})\end{array}$} & \multirow{2}{*}{$\begin{array}{l}\mathbf{T}_{\mathbf{n , b}} \\
\left({ }^{\circ} \mathbf{C}\right)\end{array}$} & \multicolumn{2}{|c|}{ Depletion } & \multirow{2}{*}{$\begin{array}{l}\text { Safety } \\
\text { Group }\end{array}$} \\
\hline & & & & & & ODP & GWP & \\
\hline $\mathrm{R}-123$ & $\mathrm{CHCl}_{2} \mathrm{CF}_{3}$ & 183.68 & 36.618 & 152.93 & 27.82 & 0.02 & 77 & B1 \\
\hline R-21 & $\mathrm{CHCl}_{2} \mathrm{~F}$ & 178.5 & 51.68 & 102.9 & 9.35 & 0.04 & 151 & B1 \\
\hline R-600 & $\mathrm{CH}_{3} \mathrm{CH}_{2} \mathrm{CH}_{2} \mathrm{CH}_{3}$ & 150.8 & 37.18 & 58.1 & -0.5 & 0 & 20 & $\mathrm{~A} 3$ \\
\hline
\end{tabular}

"ANSI/ASHRAE Standard 34 (2016).

Tables $2 \mathrm{a}$ and $\mathrm{b}$ depict some thermodynamics properties of the test fluids for both of the high-temperature and low-temperature cycles fluids. 
Table 2a. Thermodynamics Properties of the Candidate Working Fluid R-123 for the Higher Temperature Level Cycle

\begin{tabular}{|l|c|c|c|c|c|c|c|c|}
\hline \multirow{2}{*}{ Refrigerant } & \multicolumn{2}{|c|}{$\begin{array}{c}\text { Pressure } \\
(\mathbf{b a r})\end{array}$} & \multicolumn{2}{c|}{$\begin{array}{c}\text { Liquid Density } \\
\left(\mathbf{k g} / \mathbf{m}^{3}\right)\end{array}$} & \multicolumn{2}{c|}{$\begin{array}{c}\text { Liquid Enthalpy } \\
(\mathbf{k J} / \mathbf{k g})\end{array}$} & \multicolumn{2}{|c|}{$\begin{array}{c}\text { Vapor Enthalpy } \\
(\mathbf{k J} / \mathbf{k g})\end{array}$} \\
\cline { 2 - 9 } & $50{ }^{\circ} \mathrm{C}$ & $160{ }^{\circ} \mathrm{C}$ & $50{ }^{\circ} \mathrm{C}$ & $160{ }^{\circ} \mathrm{C}$ & $50{ }^{\circ} \mathrm{C}$ & $160{ }^{\circ} \mathrm{C}$ & $50{ }^{\circ} \mathrm{C}$ & $160{ }^{\circ} \mathrm{C}$ \\
\hline R-123 & 2.134 & 20.992 & 1397.8 & 974.28 & 248.92 & 378.5 & 409.97 & 459.97 \\
\hline
\end{tabular}

Table 2b. Thermodynamics Properties of Working Fluids for the LowTemperature Level Cycle

\begin{tabular}{|l|c|c|c|c|c|c|c|c|}
\hline \multirow{2}{*}{ Refrigerant } & \multicolumn{2}{|c|}{$\begin{array}{c}\text { Pressure } \\
(\mathbf{b a r})\end{array}$} & \multicolumn{2}{c|}{$\begin{array}{c}\text { Liquid Density } \\
\left(\mathbf{k g} / \mathbf{m}^{\mathbf{3}}\right)\end{array}$} & \multicolumn{2}{c|}{$\begin{array}{c}\text { Liquid Enthalpy } \\
(\mathbf{k J / k g})\end{array}$} & \multicolumn{2}{c|}{$\begin{array}{c}\text { Vapor Enthalpy } \\
(\mathbf{k J} / \mathbf{k g})\end{array}$} \\
\cline { 2 - 9 } & $35{ }^{\circ} \mathrm{C}$ & $130{ }^{\circ} \mathrm{C}$ & $35^{\circ} \mathrm{C}$ & $130{ }^{\circ} \mathrm{C}$ & $35{ }^{\circ} \mathrm{C}$ & $130{ }^{\circ} \mathrm{C}$ & $35^{\circ} \mathrm{C}$ & $130{ }^{\circ} \mathrm{C}$ \\
\hline R-123 & 1.31 & 14.638 & 1437.61 & 1132.9 & 233.29 & 340 & 400.81 & 452.44 \\
\hline R-21 & 2.534 & 23.713 & 1341.20 & 1080.5 & 236.68 & 350.52 & 464.19 & 495.15 \\
\hline R-600 & 3.257 & 26.284 & 562.270 & 417.14 & 283.17 & 554.35 & 631.96 & 746.4 \\
\hline
\end{tabular}

The R-123 and R-600 fluids were selected according to their excellent thermal performance in organic Rankine cycles (ORC), Javanshir et al. (2017), Yuan and Zhang (2019), and Tarrad (2020a, b, 2021). In addition, R-21 was investigated due to its high critical point characteristics, temperature, and pressure.

\section{Thermal Analysis}

The thermal analysis of the present compound cycle is summarized in Table 3.

Table 3. Thermal Analysis of the Compound Regenerative Organic Rankine Cycle (CRORC)

\begin{tabular}{|l|ll|}
\hline Component & Analysis \\
\hline & & \\
\hline
\end{tabular}


Table 3. (Continued)

\begin{tabular}{|c|c|c|}
\hline Component & Analysis & \\
\hline 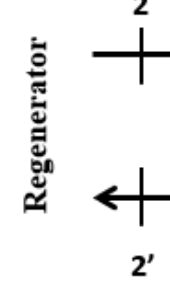 & $\begin{array}{l}\varepsilon=\frac{T_{4}-T_{4 \prime}}{T_{4}-T_{2}} \\
\varepsilon=\frac{T_{7}-T_{7 \prime}^{\prime}}{T_{7}-T_{6^{\prime}}} \\
h_{2^{\prime}}=h_{2}+h_{4}-h_{4^{\prime}} \\
h_{5}=h_{6^{\prime}}+h_{7}-h_{7^{\prime}}\end{array}$ & $\begin{array}{l}\text { (4.a) } \\
\text { (4.b) } \\
\text { (5.a) } \\
\text { (5.b) }\end{array}$ \\
\hline 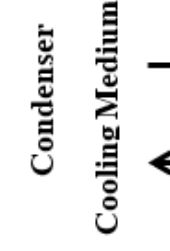 & $\begin{aligned} \dot{Q}_{\text {cond }, H . T} & =0.92 \dot{m}_{H . T}\left(h_{4^{\prime}}-h_{1}\right) \\
\dot{Q}_{\text {cond }, L . T} & =\dot{m}_{L . T}\left(h_{7^{\prime}}-h_{8}\right)\end{aligned}$ & $\begin{array}{l}\text { (6.a) } \\
(6 . b)\end{array}$ \\
\hline $\begin{array}{rr}\text { 离 } & \\
\text { L.T. } & \\
\text { 总 } & \leftarrow\end{array}$ & $\begin{array}{l}\dot{Q}_{E c o n}=0.08 \dot{m}_{H . T}\left(h_{4}-h_{1}\right) \\
h_{6 \prime}=h_{6}+\frac{\dot{Q}_{E c o n}}{\dot{m}_{L . T}}\end{array}$ & $\begin{array}{l}(7) \\
(8)\end{array}$ \\
\hline $\bar{\Xi}$ & $\begin{array}{l}\eta_{i s, p, H . T}=\frac{h_{2, i s}-h_{1}}{h_{2}-h_{1}} \\
\eta_{i s, p, L . T}=\frac{h_{6, i s}-h_{8}}{h_{6}-h_{8}} \\
\dot{W}_{p, H . T}=\dot{m}_{H . T}\left(h_{1}-h_{2}\right) / \eta_{m, p} \\
\dot{W}_{p, L . T}=\dot{m}_{L . T}\left(h_{6}-h_{8}\right) / \eta_{m, p}\end{array}$ & $\begin{array}{l}(9 . a) \\
(9 . b) \\
(10 . a) \\
(10 . b)\end{array}$ \\
\hline
\end{tabular}

The first law of thermodynamics efficiency is defined as:

$$
\eta_{n e t}=\frac{\dot{W}_{e x}-\dot{W}_{p}}{\dot{Q}_{e v a p}}
$$

Hence, the compound cycle net thermal efficiency is estimated from:

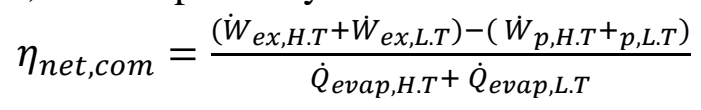

The corresponding net thermal efficiency for the two independent cycles is calculated by:

$$
\eta_{n e t, i n d}=\frac{\left(\dot{W}_{e x, H . T}+\dot{W}_{e x, f}\right)-\left(\dot{W}_{p, H . T}+\dot{W}_{p, f}\right)}{\dot{Q}_{\text {evap }, H . T}+\dot{Q}_{\text {evap }, f}}
$$


The subscription $(f)$ refers to the working fluid circulating in the lower temperature mini-cycle; this includes any of the R-123, R-21, and R-600. The parameter $\eta_{\text {net,ind }}$ is the net thermal efficiency mean value when these cycles operate independently at the two temperature levels.

The mass flow rate of the circulated fluid was calculated for the hypothetical cycles of the total $100 \mathrm{~kW}$ nominal evaporation load, for a mini-cycle of the (CRORC) and independent systems, it corresponds to:

$$
\dot{m}=\frac{50}{\left(h_{g, e v a p}-h_{x}\right)}
$$

In this expression, the heating load of each mini-cycle of the (CRORC) and independent systems possesses half of the total system nominal heat load. The $\left(h_{\text {g,evap }}\right)$ refers to the vapor enthalpy at the operating evaporator saturation temperature, Table 2 . The enthalpy $\left(h_{x}\right)$ corresponds to that at the pump discharge side; it is equal to $\left(h_{2}\right)$ and $\left(h_{6}\right)$ for the high and low-temperature mini-cycles, respectively, for the compound system. Thus, the same mass flow rates were circulated in both (CRORC) and (IRORC) systems.

$$
\dot{Q}_{\text {evap }, t}=\dot{Q}_{\text {evap }}+\dot{Q}_{\text {sup }}
$$

Table 4 illustrates the numerical values of the efficiencies of the expander and pump and the effectiveness of the regenerators.

Table 4. The Numerical Values of Performance Parameters Utilized at the Present Work

\begin{tabular}{|l|c|}
\hline Parameter & Value \\
\hline Expander isentropic efficiency, $\eta_{i s, e x}$ & $85 \%$ \\
\hline Expander volumetric efficiency, $\eta_{v, e x}$ & $85 \%$ \\
\hline Expander mechanical efficiency, $\eta_{m, e x}$ & $90 \%$ \\
\hline Pump isentropic efficiency, $\eta_{i s, p}$ & $85 \%$ \\
\hline Pump mechanical efficiency, $\eta_{m, p}$ & $80 \%$ \\
\hline Regenerator effectiveness, $\varepsilon$ & $80 \%$ \\
\hline
\end{tabular}

The evaluation of the performance comparison between different test fluids under similar operating conditions was based on the discrepancy percentage defined as:

$$
\beta_{\phi}=\frac{\phi_{n}-\phi_{r e f}}{\phi_{n}} \times 100
$$

Here, the subscriptions ( $n$ ) and ( $r e f$ ) refer to the compared fluid and reference fluid, respectively. The parameter $(\phi)$ refers to the required characteristic variable for comparison, such as $\dot{W}_{\text {pump }}, \dot{W}_{\text {exp }}, \dot{Q}_{\text {eavp }}$, and $\eta_{\text {net }}$. This expression is valid for comparing the performance of the same fluid at different operating conditions such as volumetric efficiency or evaporation temperature change. The 
comparison of the compound regenerative organic Rankine cycle (CRORC) system and the independent regenerative organic Rankine cycle (IRORC) system performance parameters were deduced from:

$$
\zeta_{\phi}=\frac{\phi_{c o m}-\phi_{\text {ind }}}{\phi_{\text {com }}} \times 100
$$

The parameter $(\phi)$ has the same definitions as those in Eq. (16). Equation (17) is valid for all of the compared parameters, $\dot{W}_{\text {pump }}, \dot{W}_{\text {exp }}$, and $\eta_{\text {net }}$ except for the consumed energy one $\left(\dot{Q}_{\text {eavp }}\right)$ which was inverted as:

$$
\zeta_{\dot{Q}_{\text {evap }}}=\frac{\dot{Q}_{\text {evap }, \text { ind }}-\dot{Q}_{\text {evap }, \text { com }}}{\dot{Q}_{\text {evap }, \text { ind }}} \times 100
$$

\section{Results and Discussion}

\section{Energy Consumption}

Figure 3 illustrates a comparison of the extracted heating load from the waste for the compound and independent systems.

Figure 3. Comparison of Energy Recovery Between the (CRORC) and (IRORC)

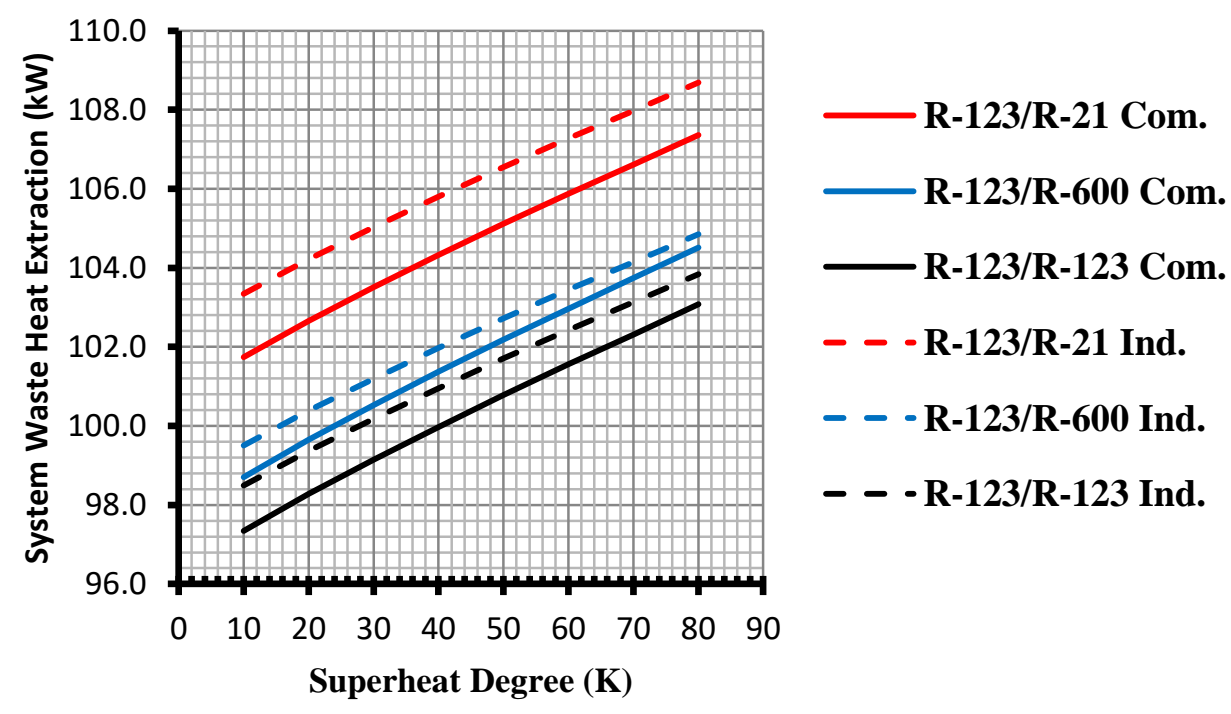

The results show that the compound system requires less energy than the independent arrangement to produce equal net output power. The pair R-123/R-21 absorbed the highest heating load for both systems, followed by the R-123/R-600 pair, and the R-123/R-123 system absorbed the minimum heat load. The increase of the energy extraction for the independent system was higher than that of the compound system, with $2 \%$ for all of the test pairs. Figure 4 depicts the heat load distribution percentage for each compound system pair at $80{ }^{\circ} \mathrm{C}$ superheat degree. 
Figure 4. The Compound System Energy Distribution at (80) ${ }^{\circ} \mathrm{C}$ Superheat Degree

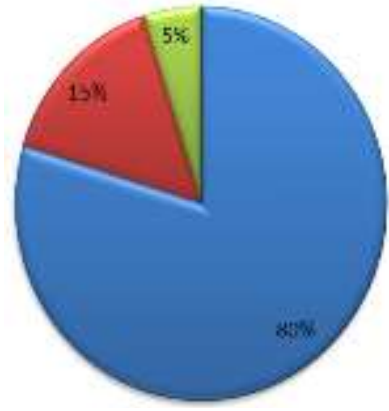

Figure 4a. $R-123 / R-600$

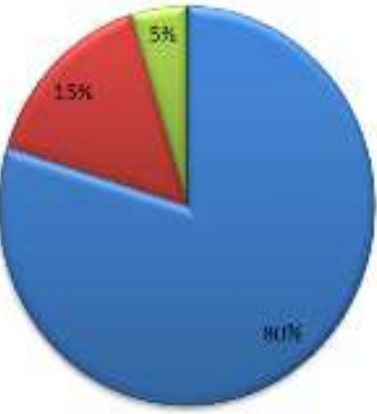

Figure 4b. $R-123 / R-21$

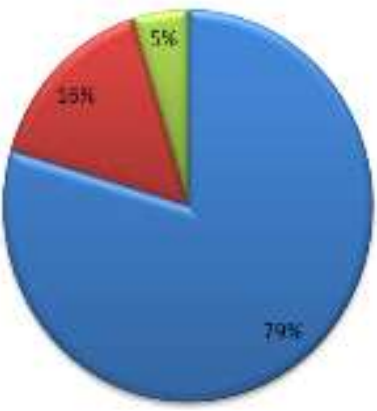

Figure 4c. $R-123 / R-123$ a Condenser

Net Power

uLosses

These results show that the heat transfer domain is shared similarly for all of the test fluid pairs. The condensation load occupies about $80 \%$ of the total consumed energy in the boiler. The green sector corresponds to $5 \%$; it refers to the losses that accompany the thermal and mechanical efficiencies of the actuators and the regenerators installed in the cycles. Figure 5 depicts the energy distribution of the independent system at $80{ }^{\circ} \mathrm{C}$. The net power output of all test fluid pairs is equal; the R-123/R-123 exhibited the higher condensation and lower losses components as $82 \%$ and $3 \%$, respectively.

Figure 5. The Independent System Energy Distribution at $80^{\circ} \mathrm{C}$ Superheat Degree

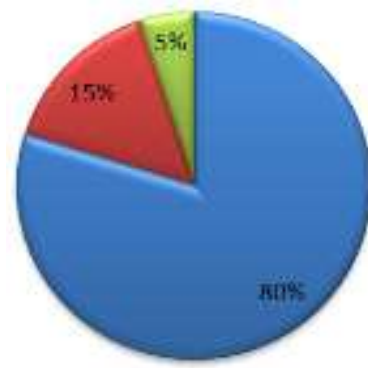

Figure 5a. $R-123 / R-600$

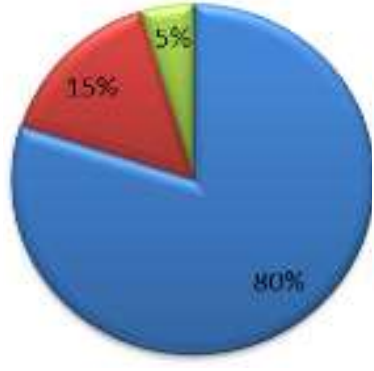

Figure 5b. $R-123 / R-21$

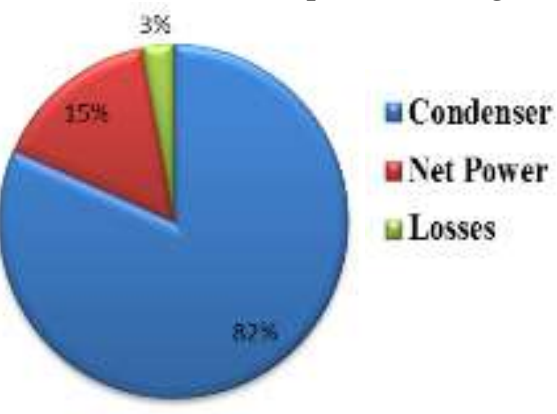

Figure 5c. $R-123 / R-123$

The energy distribution of the compound system at $10{ }^{\circ} \mathrm{C}$ superheat degree in the high-temperature mini-cycle for all of the examined fluids was 5\%,14\%, and $81 \%$ for the losses, net power output, and condensation load parts.

All of the tested pairs for the compound system showed similar values for energy distribution. The condensation load for the condenser of both mini-cycles occupies $81 \%$ of the total energy consumption in the boiler. Therefore, the rejected heat load in the condensers could be used with a suitable system arrangement to provide hot water for heating or daily human needs. The energy distribution in the high-temperature mini-cycle of the compound system is shown in Figure 6 at different superheat degrees. 
Figure 6. The High-Temperature Mini-Cycle Energy Distribution

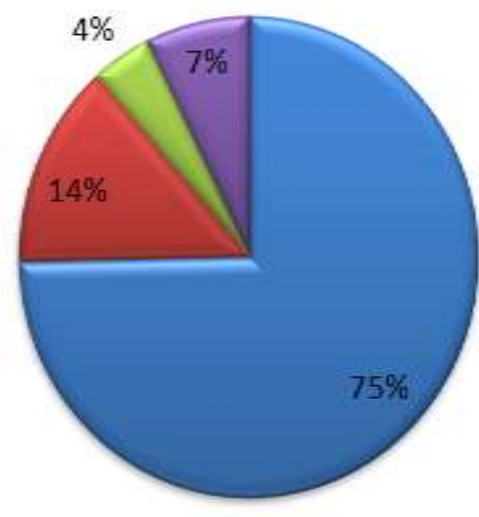

Figure 6a. $\Delta T_{s u p}=10^{\circ} \mathrm{C}$

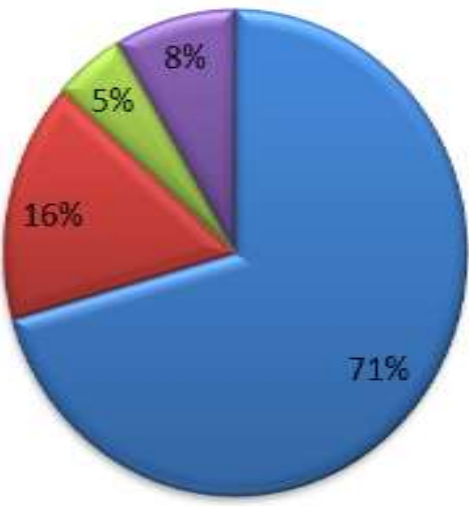

a Condenser

Net Power

Losses

Economizer

The economizer occupies the range of $7-8 \%$ of the total extracted waste energy in the boiler. This amount of energy is added to the low-temperature minicycle to minimize the total energy consumed by the system.

\section{Net Power Output}

Figure 7 illustrates the net power output of the examined compound systems for the tested fluid pairs and operating conditions.

Figure 7. Comparison of System Net Power Output of (CRORC) for the Test Fluid Pairs

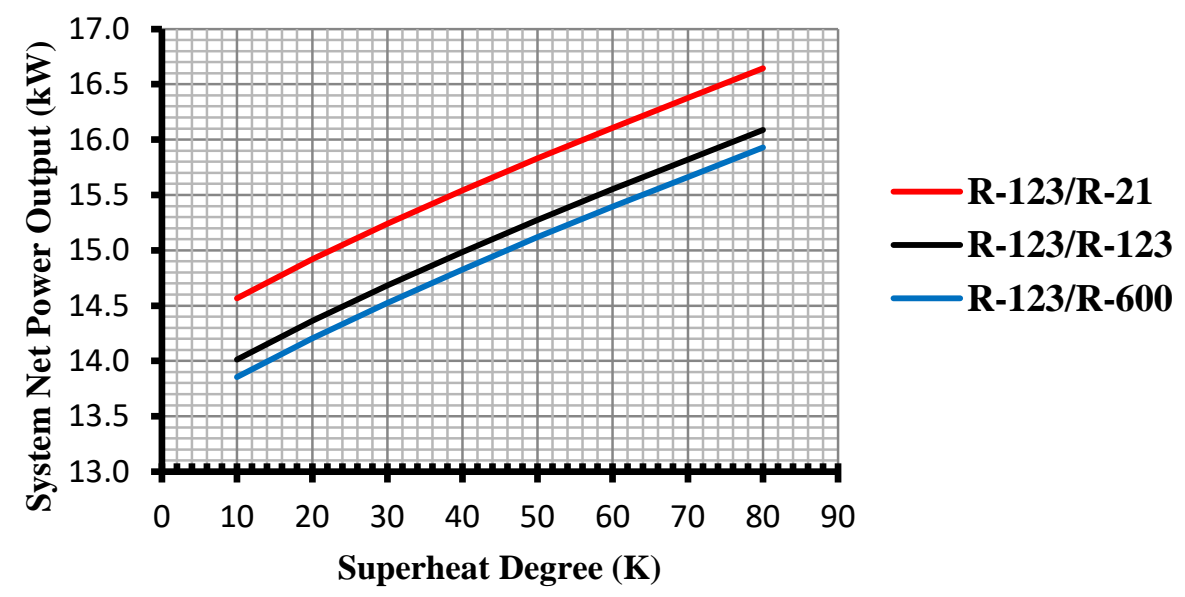

The system net power output showed an enhancement as the superheat degree increases. For example, as the superheat degree was increased from $10{ }^{\circ} \mathrm{C}$ to 80 ${ }^{\circ} \mathrm{C}$, the system net power output for the R-123/R-123 and R-123/R-600 was augmented by $13 \%$. The corresponding enhancement for the R-123/R-21 system was $12.5 \%$ for the same operating conditions. As a result, the maximum system net power output was produced by the R-123/R-21 system and approached a value 
of $16.6 \mathrm{~kW}$ at $80{ }^{\circ} \mathrm{C}$ superheat degree. At the same superheat degree, the R-123/R123 and R-123/R-600 systems had $16.1 \mathrm{~kW}$ and $15.9 \mathrm{~kW}$, respectively.

\section{Net System Efficiency}

A comparison of the system net thermal efficiency between both test systems, compound and independent, for the examined fluid pairs is shown in Figure 8.

Figure 8. Comparison of System Net Power Efficiency of the (CRORC) and (IRORC) for Test Fluid Pairs

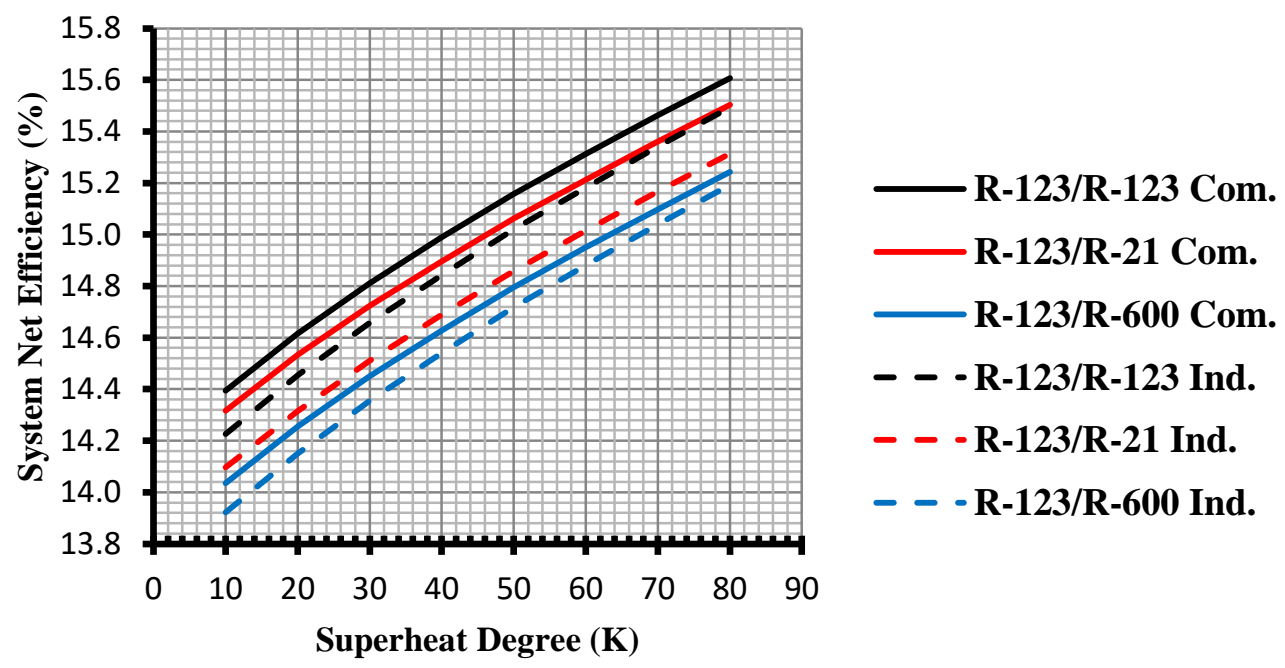

The compound system showed higher net thermal efficiency than the independent one with up to $2 \%$. The R-123/R-123 and R-123/R-600 fluid pairs exhibited higher and lower thermal efficiency values, respectively, in both systems. The R-123/R-123 and R-123/R-21 compound systems revealed higher thermal efficiency than R-123/R-600 one by $3 \%$ and $2 \%$ respectively for the superheat degree range of $10-80{ }^{\circ} \mathrm{C}$ in the high-temperature mini-cycle. R-123/R123 and R-123/R-600 systems produced a thermal efficiency in the range of 14.415.6 and $14-15.2 \%$, respectively, for the superheat degree range of $10-80{ }^{\circ} \mathrm{C}$, Figure 9. R-123/R-21 compound system achieved close results to those of the R123/R-123 within the scope of $14.3-15.5 \%$. 
Figure 9. A Comparison of the Compound System Net Thermal Efficiency at Different Superheat Degrees

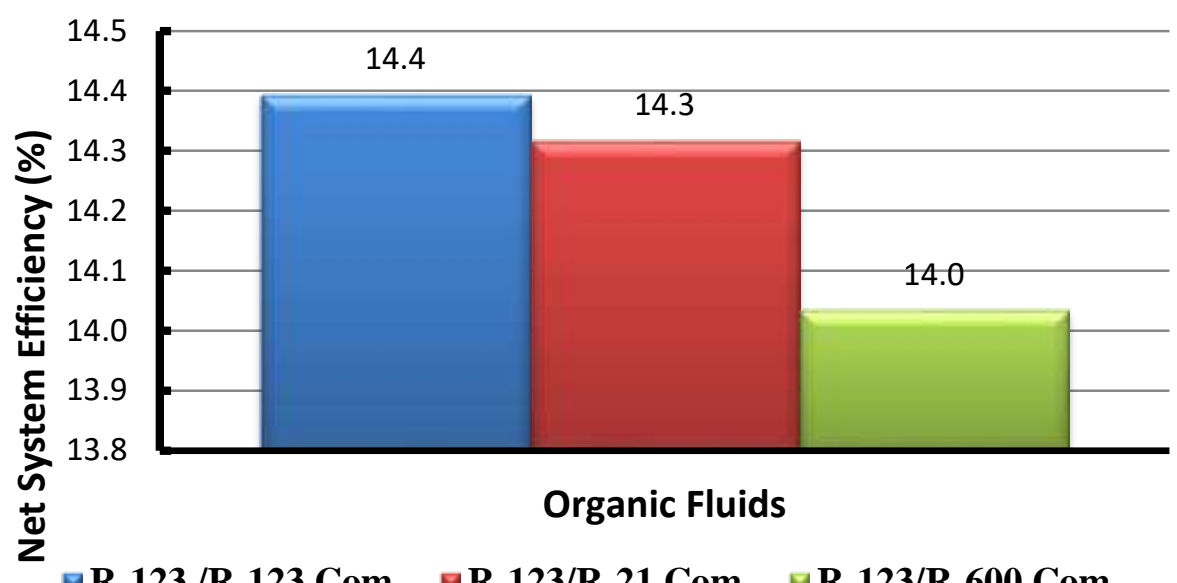

Figure 9a. $\Delta T_{\text {sup }}=10{ }^{\circ} \mathrm{C}$

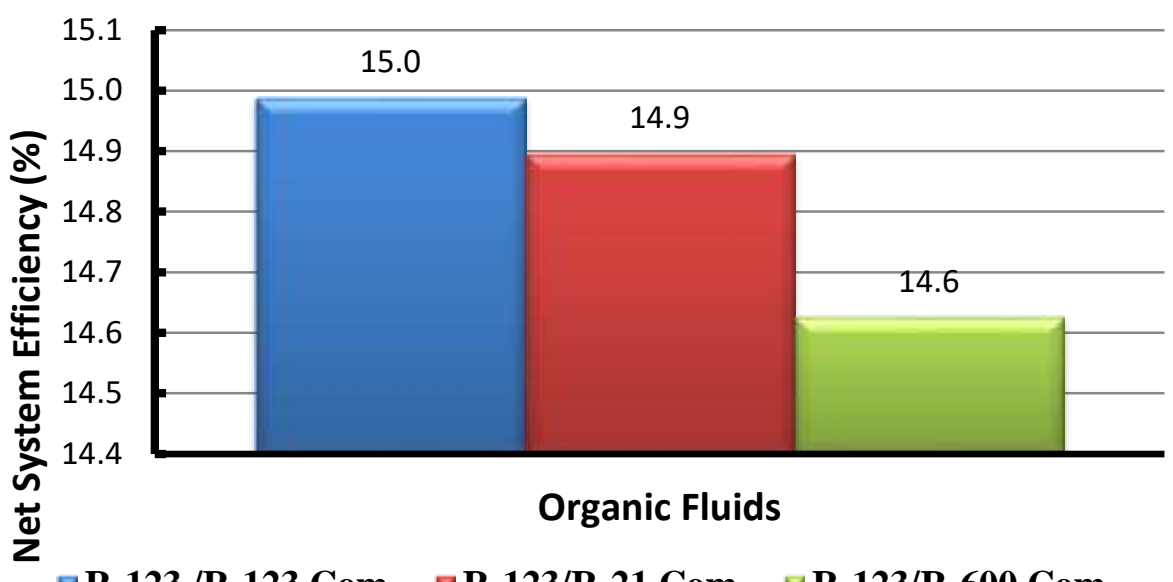

Figure 9b. $\Delta T_{\text {sup }}=40{ }^{\circ} \mathrm{C}$

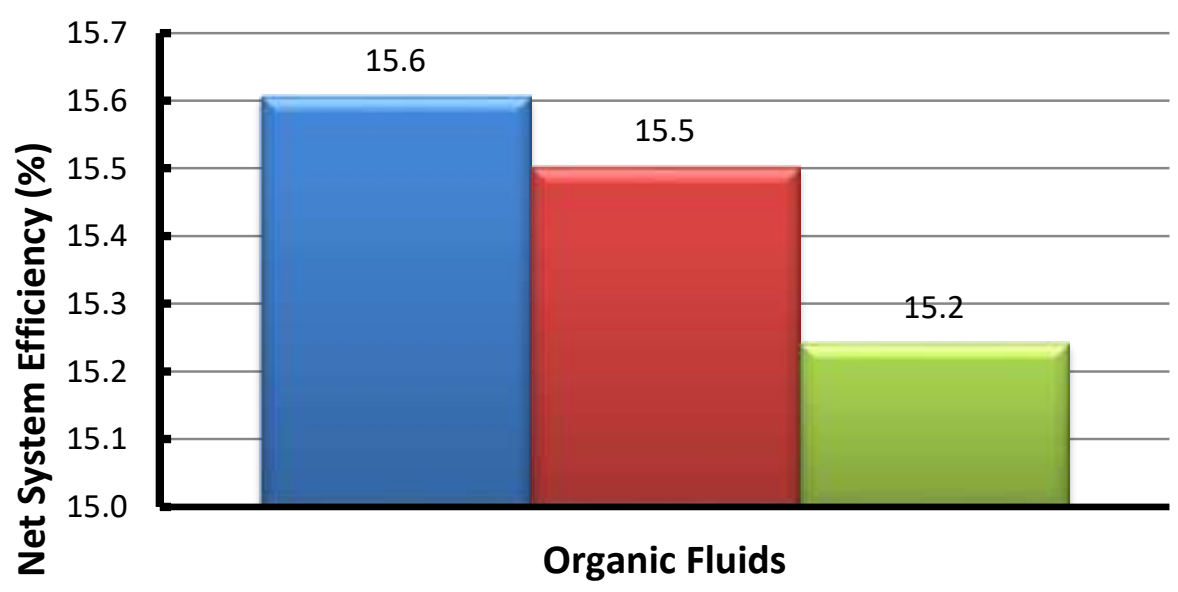

口R-123 /R-123 Com. घR-123/R-21 Com. $\square$ R-123/R-600 Com.

Figure 9 c. $\Delta T_{\text {sup }}=80^{\circ} \mathrm{C}$ 
The numeric values revealed that the thermal efficiency experienced an increase when the superheat degree was raised from $10{ }^{\circ} \mathrm{C}$ to $80{ }^{\circ} \mathrm{C}$ for the hightemperature mini-cycle fluid. R-123/R-600, R-123/R-123, and R-123/R-21 thermal efficiency at $80{ }^{\circ} \mathrm{C}$ superheat degree for the compound system were higher than those at $10{ }^{\circ} \mathrm{C}$ superheat degree ones by $7.9 \%, 7.8 \%$, and $7.6 \%$, respectively. The corresponding enhancement values were $8.4 \%, 8.2 \%$, and $8 \%$ for R-123/R$600, \mathrm{R}-123 / \mathrm{R}-123$, and R-123/R-21, respectively, in the independent arrangement when the superheat degree was increased from $10{ }^{\circ} \mathrm{C}$ to $80^{\circ} \mathrm{C}$.

\section{Low-Temperature Mini-Cycle Efficiency}

Figure 10 illustrates a comparison of the thermal efficiency of the lowtemperature mini-cycle of the compound cycle for the examined fluids.

Figure 10. Comparison of the Net Thermal Efficiency of Low-Temperature MiniCycle in the Compound System for Test Fluids

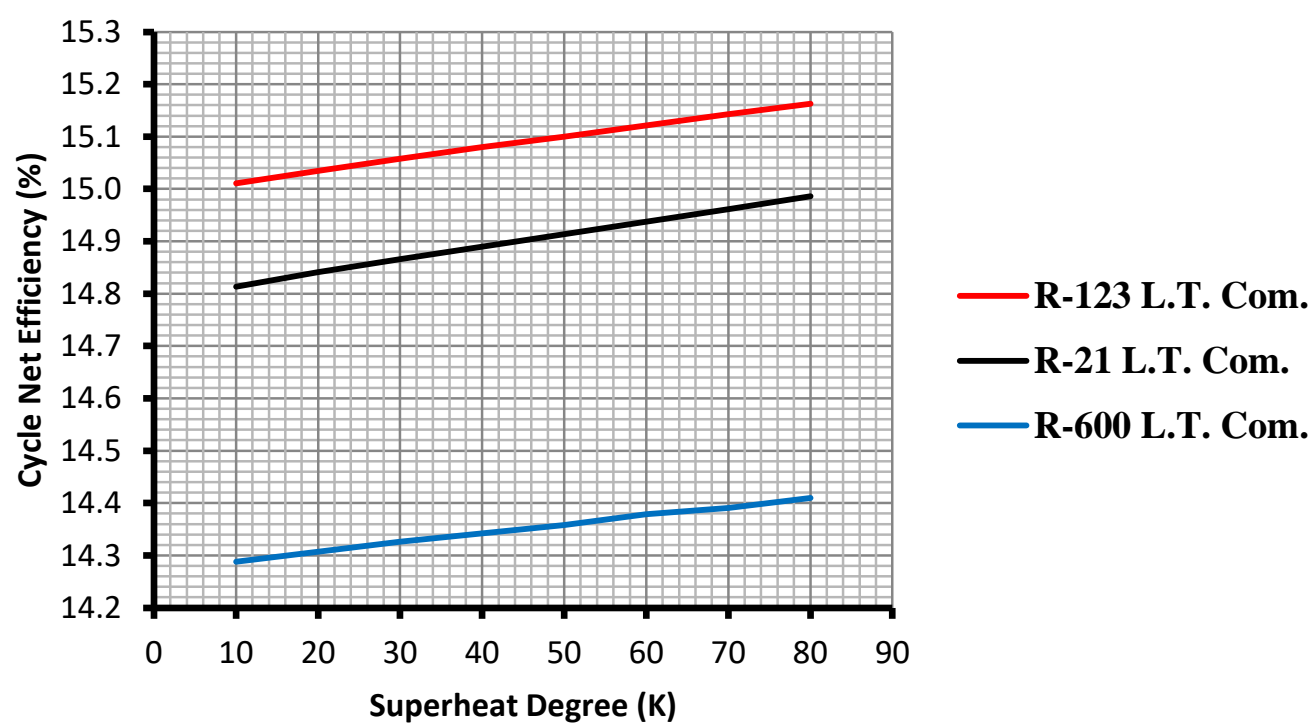

The R-123 fluid exhibited the highest thermal efficiency; it corresponds to the range of $15-15.2 \%$. It is followed by the R-21 system, where it occupies $14.8-15 \%$, whereas the R-600 fluid produced the lower thermal efficiency in the range of 14.3-14.4\%, Figure 11. 
Figure 11. Comparison of Cycle Net Efficiency of the Low-Temperature MiniCycle at Different Superheat Degrees

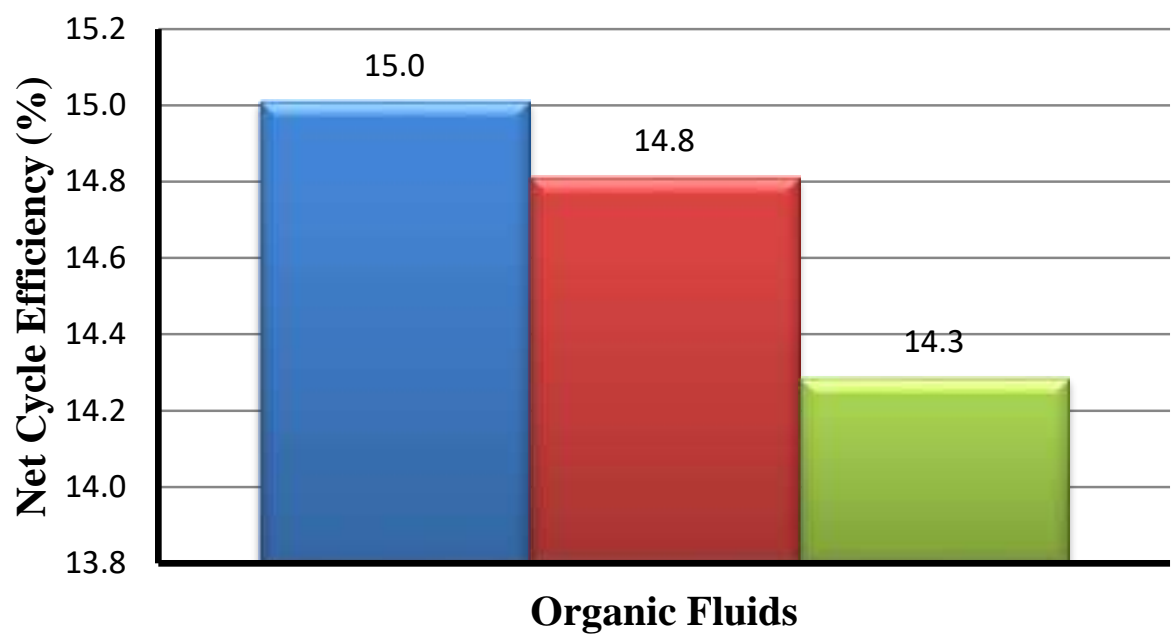

$\square$ R-123 L.T. Com. $\square$ R-21 L.T. Com. $\square$ R-600 L.T. Com.

Figure 11a. $\Delta T_{\text {sup }}=10^{\circ} \mathrm{C}$

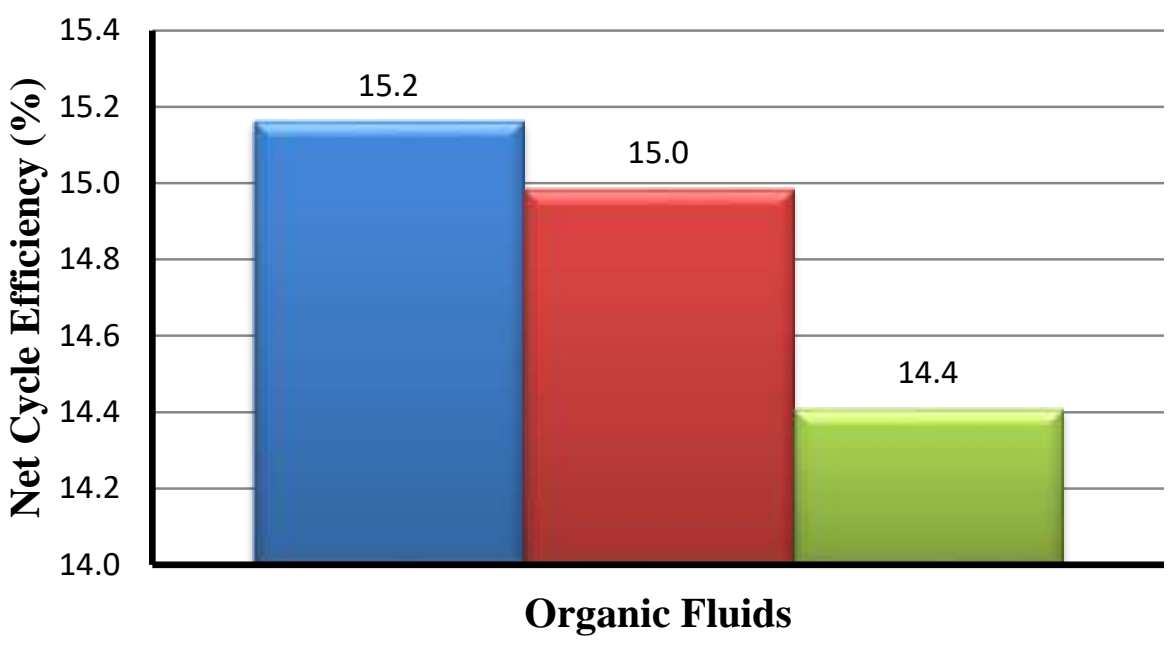

घR-123 L.T. Com. $\square$ R-21 L.T. Com. $\square$ R-600 L.T. Com.

Figure 11b. $\Delta T_{\text {sup }}=80^{\circ} \mathrm{C}$

The results showed that R-123 and R-21 provided higher net thermal efficiency than the R-600 for the examined operating conditions in the range of 4.7-5.3\% and 3.4-4.2\%, respectively. The compound low-temperature mini-cycle thermal efficiency was higher than that of the low-temperature independent system for all tested fluids. R-123, R-21, and R-600 fluids thermal efficiency in the compound system were higher than those of the independent cycle by the range of $3-4 \%$, 3.6-4.7, and 2.3-3\%, respectively. 


\section{Conclusions}

The present work revealed the importance of utilizing the compound system at low and moderate waste energy source temperatures. Therefore, the following facts were withdrawn as:

- The required energy extraction for the independent system to achieve similar net power output as that of the compound system was higher by a maximum of $2 \%$.

- The net thermal efficiency of the compound system was higher than that of the independent system by a maximum of $2 \%$ when operates under similar operating conditions.

- The compound system provided a thermal efficiency of $14-15.6 \%$ for the examined fluid pairs. The R-123/R-123 provided the maximum thermal efficiency, followed by R-123/R-21 and the R-123/R-600 pair possessed the minimum.

- The low-temperature mini-cycle of the compound system showed thermal efficiency enhancement of 3-4\%, 3.6-4.7, and 2.3-3\% for the R-123, R-21, and R-600 fluids, respectively, when compared to those of the independent cycle.

- Increasing the superheat degree of the high-temperature mini-cycle from $10{ }^{\circ} \mathrm{C}$ to $80{ }^{\circ} \mathrm{C}$ for the compound system has improved the thermal efficiency by $7.9 \%, 7.8 \%$, and $7.6 \%$ for the R-123/R-600, R-123/R-123, and R-123/R-21, respectively.

\section{Acknowledgments}

The author would like to express his sincere thanks to the Laboratoire Énergies \& Mécanique Théorique et Appliquée (LEMTA) of the University of Lorraine for their valuable support. Thanks are also extended to the administration of the (PAUSE) program of Collège de France for allowing the author to pursue his research activities.

$\begin{array}{ll}\text { Nomenclature } \\ \text { Parameter } & \text { Definition } \\ h & \text { Fluid specific enthalpy, }(\mathrm{kJ} / \mathrm{kg}) \\ M_{w} & \text { Fluid molecular weight, } \mathrm{kg} / \mathrm{kmol} \\ \dot{m} & \text { Fluid mass flow rate, }(\mathrm{kg} / \mathrm{s}) \\ P & \text { Fluid working pressure, }(\mathrm{bar}) \\ \dot{Q} & \text { Heat transfer rate },(\mathrm{kW}) \\ S & \text { Fluid specific entropy, }(\mathrm{kJ} / \mathrm{kg}) \\ T & \text { Fluid temperature },\left({ }^{\circ} \mathrm{C}\right) \\ \dot{W} & \text { Power, }(\mathrm{kW})\end{array}$




$\begin{array}{ll}\begin{array}{l}\text { Subscription } \\ \text { Parameter }\end{array} & \text { Definition } \\ c & \text { Critical point } \\ \text { com } & \text { Compound } \\ \text { cond } & \text { Condenser } \\ \text { evap } & \text { Evaporator } \\ \text { ex } & \text { Expander } \\ g & \text { Gas condition } \\ \text { H.T } & \text { High-temperature side } \\ i & \text { Inlet side } \\ \text { ind } & \text { Independent } \\ \text { is } & \text { Isentropic } \\ \text { L.T } & \text { Low-temperature side } \\ n & \text { Fluid, normal point } \\ \text { net } & \text { Net value } \\ p & \text { Feed pump } \\ \text { ref } & \text { Reference fluid } \\ \text { sup } & \text { Superheated vapor } \\ t & \text { Total } \\ \text { ter } & \text { Terminal } \\ v & \text { Volumetric }\end{array}$

\section{Greek Letter}

$\beta \quad$ Deviation percentage, $(\%)$

$\varepsilon \quad$ Heat exchanger effectiveness, $(\%)$

$\zeta \quad$ Deviation, $(\%)$

$\eta \quad$ Cycle thermal efficiency, $(\%)$

$\phi \quad$ Characteristic parameter

$\begin{array}{ll}\begin{array}{l}\text { Abbreviations } \\ \text { Parameter }\end{array} & \begin{array}{l}\text { Definition } \\ \text { CRORC }\end{array} \\ & \begin{array}{l}\text { Compound Regenerative Organic } \\ \text { Rankine Cycle }\end{array} \\ \text { GWP } & \text { Global Warming Potential } \\ \text { IRORC } & \begin{array}{l}\text { Independent Regenerative Organic } \\ \text { Rankine Cycle }\end{array} \\ \text { ODP } & \text { Ozone Depletion Potential } \\ \text { ORC } & \text { Organic Rankine Cycle }\end{array}$




\section{References}

ANSI/ASHRAE (2016) Standard 34, designation and safety classification of refrigerants.

Astina I (2010) Alternative systems for enhancing geothermal power plan. In The 2nd AUN/SEED-Net Regional Conference on New and Renewable Energy, 1-12. Faculty of Engineering, Burapha University, Thailand. January 21-22, 2010.

Da Cunha AFV, Souza SLS (2020) Analysis of R134a organic regenerative cycle. Journal of Power and Energy Engineering 8(5): 32-45.

Javanshir A, Sarunac N, Razzaghpanah Z (2017) Thermodynamic analysis of a regenerative organic Rankine cycle using dry fluids. Applied Thermal Engineering 123(May): 852-864.

Jung HC, Taylor L, Krumdieck S (2015) An experimental and modelling study of a $1 \mathrm{~kW}$ organic Rankine cycle unit with mixture working fluid. Energy 81(Mar): 601-614.

Mishra RS, Khan Y (2017) Exergy and energy analysis of modified organic Rankine cycle for reduction of global warming and ozone depletion. International Journal of Research in Engineering and Innovation 1(3): 1-12.

Molés F, Navarro-Esbrí J, Peris B, Mota-Babiloni A, Barragán-Cervera Á, Kontomaris KK (2014) Low GWP alternatives to HFC-245fa in organic Rankine cycles for lowtemperature heat recovery: HCFO-1233zd-E and HFO-1336mzz-Z. Applied Thermal Engineering 71(1): 204-212.

Pandey S, Dwivedi A, Ahmad S, Arora A (2018) Parametric analysis of geothermal organic Rankine cycle working on zeotropic mixture of R600a/DME. International Journal of Advanced Production and Industrial Engineering 3(3): 33-46.

Shengjun Z, Huaixin W, Tao G (2011) Performance comparison and parametric optimization of subcritical organic Rankine cycle (ORC) and transcritical power cycle system for low-temperature geothermal power generation. Applied Energy 88(8): 2740-2754.

Tarrad AH (2020a) A steady-state evaluation of simple organic Rankine cycle (SORC) with low-temperature grade waste heat source. Journal of Power and Energy Engineering 8(7): 15-31.

Tarrad AH (2020b) A comparative study for the organic Rankine cycle coupled with lowtemperature grade waste energy source. International Journal of Latest Engineering Research and Applications (IJLERA) 5(7): 11-26.

Tarrad AH (2021) A perspective evolution methodology of energy management in a subcritical regenerative organic Rankine cycles operate at two temperature levels. Athens Journal of Technology and Engineering 8(1): 9-26.

Xi H, Ming-Jia L, Chao X, Ya-Ling H (2013) Parametric optimization of regenerative organic Rankine cycle (ORC). Energy 58(Sep): 473-482.

Yazdi AJ (2017) Investigation of different models of combined parallel flash binary cycles. International Journal of Engineering Sciences \& Research Technology 6(2): 139-147.

Yuan P, Zhang C (2019) Comparison on thermodynamic performances between basic and regenerative sub-critical organic Rankine cycles coupled with low-grade heat source. In IOP Conf. Series: Materials Science and Engineering, 473, Article ID: 012031.

Vankeirsbilck I, Vanslambrouck B, Gusev S, De Paepe M (2011) Organic Rankine cycle as efficient alternative to steam cycle for small scale power generation. In $8^{\text {th }}$ International Conference on Heat Transfer, Fluid Mechanics, and Thermodynamics (HEFAT2011), 785-792. Pointe Aux Piments, Mauritius. 11-13 July 2011. 
